\title{
Cultivar Effects on the Interaction between Free-Living Plant-Parasitic Nematodes and the Fungal Pathogen Rhizoctonia solani in Potato
}

\author{
Maria Viketoft $^{1}$ (D) Annhild Andersson ${ }^{1} \cdot$ Eva Edin $^{2}$ \\ Published online: 7 February 2017 \\ (C) The Author(s) 2017. This article is published with open access at Springerlink.com
}

\begin{abstract}
Crop damage is associated with infection by plant pathogens but can also arise through abiotic factors. However, the plant pathogens are involved in biotic interactions with other plant pathogens, and these interactions may differ depending of the cultivar of the crop. Here, the interaction between the fungus Rhizoctonia solani (AG3) and free-living plant-parasitic nematodes was investigated in a pot experiment with different potato cultivars. No synergistic interaction between $R$. solani and plant-parasitic nematodes was found, instead there was an effect of treatment with lower tuber yield when nematodes occurred alone. There were differences among the cultivars regarding incidence of black scurf, dry weight of stems and tubers, and there was interactive effects between treatment and cultivar regarding dry weight of stolons and roots. Therefore, results concerning incidence and damage of $R$. solani and/or plant-parasitic nematodes found for one cultivar may not be applicable to other cultivars.
\end{abstract}

Resumen El daño en el cultivo se asocia con infección por fitopatógenos, pero también puede surgir a través de factores abióticos. No obstante, los patógenos de plantas están involucrados en interacciones bióticas con otros patógenos,

Electronic supplementary material The online version of this article (doi:10.1007/s12230-017-9567-3) contains supplementary material, which is available to authorized users.

Maria Viketoft

maria.viketoft@slu.se

1 Department of Ecology, Swedish University of Agricultural Sciences (SLU), PO Box 7044, 75007 Uppsala, Sweden

2 Department of Forest Mycology and Plant Pathology, Swedish University of Agricultural Sciences (SLU), PO Box 7026, 750 07 Uppsala, Sweden y estas interacciones pudieran diferir dependiendo de la variedad del cultivo. Aquí, se investigó la interacción entre el hongo Rhizoctonia solani (AG3) y nematodos fitoparásitos de vida libre en un experimento en macetas con diferentes variedades de papa. No se encontró una interacción sinergística entre $R$. solani y los nematodos fitoparásitos, en cambio, hubo un efecto de tratamiento con rendimiento más bajo de tubérculo cuando los nematodos estaban solos. Hubo diferencias entre variedades en relación a la incidencia de costra negra, peso seco de los tallos y los tubérculos, y hubo efectos interactivos entre tratamiento y variedad en relación al peso seco de los estolones y las raíces. De aquí que los resultados concernientes a la incidencia y daño de $R$. solani y/o nematodos fitoparásitos que se encontraron para una variedad pudieran no ser aplicables a otras.

Keywords Black scurf · Disease complex · Elephant hide · Fungal-feeding nematodes $\cdot$ Pratylenchus $\cdot$ Stem canker

\section{Introduction}

Development of disease in cultivated crops is a complex relationship between crop, pathogen and prevailing environmental conditions (Wallace 1978). On the other hand, plant pathogens are also subjected to biotic interactions with other plant pathogens. In many crops throughout the world, it has been demonstrated that nematodes play a significant role for the development of diseases caused by other soil-borne pathogens, and particularly prevalent are synergistic interactions between plant-parasitic nematodes and species of pathogenic fungi (Back et al. 2002). Synergistic interactions occur when the combined damage is more severe than the sum of the separate damages. For example, in the 'potato early dying'complex, nematodes activate low populations of Verticillium 
dahliae that would otherwise be of minor significance in causing disease (e.g. Bowers 1996; Evans 1987). It is therefore essential to understand and appreciate the importance of each such relationship between pathogens in order to control disease through appropriate management methods.

Stem canker and other symptoms caused by the plant pathogenic fungus Rhizoctonia solani Kühn are considered a major problem for potato growers in Sweden, especially in conventional growing systems, which often have shorter crop rotations. The fungus can attack all parts of the potato plant (Banville 1989; Carling et al. 1989; Muzhinji et al. 2014). The sprouting stem may get necrotic lesions and eventually become girdled and die (stem canker). The roots and stolons may also get necrotic lesions and be discolored. The tubers do often have sclerotia on the skin (black scurf), cracks in the skin (elephant hide), or narrow holes in the tuber (dry core) and they may also be deformed. Rhizoctonia solani is often reported to be involved in disease complexes with nematodes. In potato, the interactions between $R$. solani and the potato cyst nematodes Globodera rostochiensis (Back et al. 2006, 2010) and Globodera pallida (Bhattarai et al. 2009, 2010) have been quite well studied, and the interaction between the root-lesion nematode Pratylenchus penetrans and $R$. solani result in lower tuber yield (Kotcon et al. 1985; Viketoft et al., unpublished data).

However, not all potatoes are alike and there are differences among cultivars in their susceptibility to $R$. solani and nematode infection. Severity of stem canker have been found to differ among cultivars (El Aziz et al. 2013; Zhang et al. 2014), but the severity of black scurf may (Djébali and Belhassen 2010) or may not (El Aziz et al. 2013; Sedláková et al. 2013) be affected by cultivar. Regarding plant-parasitic nematodes, cultivars may differ in their suitability as host plants supporting nematode reproduction. Two populations of Naccobus aberrans were not able to reproduce on some cultivars (Lax et al. 2013), and reproduction of nematodes belonging to the genus Meloidogyne differed among red-skinned potato cultivars (Kandouh and Sipes 2014). Nematodes may also affect tuber yield in various ways depending on cultivar. For root-lesion nematodes, yields were related to the tolerance of the cultivars to nematode colonization (Bernard and Laughlin 1976), and for root-knot nematodes the tuber weight differed among cultivars across nematode species (Kandouh and Sipes 2014). For example, the tuber weight of three of the investigated cultivars was reduced by Meloidogyne incognita but not by the other root-knot nematode species. In addition, the tuber weight loss of potato cultivars subjected to Ditylenchus destructor and Ditylenchus dipsaci ranged from $1 \%$ to $87 \%$ (Mwaura et al. 2015).

Nonetheless, the effects of cultivars on the interactions between nematodes and pathogenic fungi are not as well studied, but the potato cyst nematode $G$. pallida has been found to assist $V$. dahliae in evading the natural defences of the root by opening an invasion channel for the fungus (Storey and Evans 1987). However, in the cultivars Maris Anchor and Maris Peer, but not in Pentland Javelin, the nematode provoked a widespread hypersensitive response that resulted in cell wall lignification that impeded the growth of hyphae that invaded several days after the nematode (Storey and Evans 1987).

In this study, we aimed to investigate the cultivar effect on the interaction between $R$. solani and free-living plant-parasitic nematodes, dominated by root-lesion nematodes (Pratylenchus crenatus and P. neglectus). This was done by controlling the presence and/or abundance of the pathogens in a pot experiment. The hypotheses were (1) that there would be a synergistic interaction between $R$. solani and free-living plant-parasitic nematodes resulting in lower tuber yield when the organisms occurred together, as previously found for cv. King Edward (Viketoft et al., unpublished data), and (2) that the cultivars would respond differently to the treatments.

\section{Material and Methods}

\section{Organisms}

\section{Potatoes}

Mini-tubers produced from meristem cultures of the cultivars Erika, Fontane, King Edward VII, Kuras, Perlo and Rosagold were purchased from Agrico Nordic AB, but they were cultivated at The Finnish Seed Potato Centre Ltd. (SPK), Tyrnävä, Finland, during spring 2013. These cultivars were chosen to provide a mixture of early and late maturing cultivars, and differing susceptibility to spraing (vectored by nematodes) and potato cyst nematodes (Table 1). Screening for susceptibility to $R$. solani is not performed for the different cultivars as a lot of other things also affect the development of the fungus, e.g. germination, the amount of sclerotia on the seed tubers and the weather (Niels Jørgen Kristensen, AKV Langholt, personal communication). The tubers were put in dark cold storage $\left(4^{\circ} \mathrm{C}\right)$ and then in a glasshouse for sprouting three weeks before planting. Due to very good sprouting climate, germination progressed rapidly and consequently the seed tubers were returned to $4{ }^{\circ} \mathrm{C}$ under day/night conditions until planting.

\section{Fungus}

An isolate of $R$. solani, anastomosis group 3 (AG3), originating from Vara, Sweden, was kindly provided by Dr. S. Ahlström at the Department of Forest Mycology and Plant Pathology, SLU, Uppsala, Sweden. One small piece of mycelium growing on half strength potato dextrose agar (PDA) was added to each of ten petri dishes containing $20 \mathrm{ml}$ half strength potato dextrose broth (PDB) and left for a week on the bench for the mycelium to grow. At inoculation, the filamentous mycelium was harvested 
Table 1 Characteristics of the used potato cultivars

\begin{tabular}{|c|c|c|c|c|c|c|c|}
\hline Cultivar & Maturity & Skin color & Flesh color & Tuber shape & Average yield & $\mathrm{PCN}^{\mathrm{a}}$ resistance & Spraing \\
\hline Erika & Summer & Yellow & Yellow & Long oval & High & Ro $1 / 4$ & Resistant \\
\hline Fontane & Early autumn & Bright yellow & Bright yellow & Oval & Very high & Ro $1 / 4$ & Resistant \\
\hline King Edward & Late autumn & Yellow/Red & White & Round oval & High & Susceptible & Susceptible \\
\hline Kuras $^{\mathrm{b}}$ & Starch potato & Yellow & White & Round oval & High & Ro $1 / 4$ & Susceptible \\
\hline Perlo & Summer/early autumn & Yellow & Yellow & Round & Very high & Ro $1 / 4$ & Quite resistant \\
\hline Rosagold & Autumn & Red & Yellow & Round oval & High & Ro $1 / 4$ & Quite resistant \\
\hline
\end{tabular}

All cultivars have tubers of medium size. Data from the producer Agrico Nordic AB

${ }^{a} P C N$ potato cyst nematode, Ro 1/4 Globodera rostochiensis pathotype 1 and 4

${ }^{\mathrm{b}}$ As a starch potato Kuras has medium sized tubers and average yield, but compared to table potatoes its tubers are bigger and the average yield is also higher

and washed with phosphate-buffered saline buffer (PBS). The liquid was pressed out and the mycelium was weighed. The mycelium was carefully mixed with a clean hand blender in $100 \mathrm{ml}$ of tap water to receive as small pieces as possible. The mycelium was then suspended in tap water to correspond to the same inoculation volume as for the nematodes.

\section{Nematodes}

A full nematode community was derived from soil collected in a potato field in the county of Östergötland, in the middle part of Sweden. The nematodes were extracted with Whitehead and Hemming trays (Whitehead and Hemming 1965). After $24 \mathrm{~h}$, the water from the trays was poured into glass beakers, put in $4{ }^{\circ} \mathrm{C}$ for sedimentation, after which the amount of water was reduced and gathered in a $3 \mathrm{~L}$ glass beaker. Until inoculation, the beaker with the nematode suspension was stored cold $\left(4^{\circ} \mathrm{C}\right.$ ) and aerated with an aquarium air pump (SuperFish Air-Flow mini) connected to an airstone. To determine the amount of nematode inoculum needed, the concentration of plant-parasitic nematodes in the suspension was determined by counting the number of plant-parasitic nematodes in five replicates of $2 \mathrm{ml}$ samples in a counting disc. During inoculation of the pots, three samples were taken from the nematode suspension for later determination of the composition of the nematode community added to the pots.

\section{Experimental Setup}

The experiment was designed as a pot experiments with each of the six potato cultivars being subjected to four different treatments: 1) control (C); 2) the fungus $R$. solani (F), $40 \mu \mathrm{g}$ $\mathrm{g}^{-1}$ sand; 3) a full nematode community (N), 2 plant-parasitic nematodes $\mathrm{g}^{-1}$ sand; and 4 ) the fungus and nematodes together $(\mathrm{F}+\mathrm{N})$. The selected nematode density corresponds to the damage thresholds for root-lesion nematodes (Bernard and Laughlin 1976; Olthof 1983, 1990). Each treatment was replicated six times giving 144 pots in total.
Pots (12x12x25 cm, drainage holes covered with filter paper) were filled with $1600 \mathrm{~g}$ of washed, sterilized sand $(0$ $3 \mathrm{~mm} \mathrm{Ø;200}{ }^{\circ} \mathrm{C}$ for $6 \mathrm{~h}$ ) and $200 \mathrm{ml}$ of tap water was added. One pre-germinated mini-tuber was placed in each pot and covered with $960 \mathrm{~g}$ sterilized sand. The pots were then watered with $100 \mathrm{ml}$ of tap water and covered with aluminum foil to provide good moisture until the shoots emerged. The day after planting the seed tubers, nematodes, fungus and water was added to the pots: control (tap water), fungus ( $0.1 \mathrm{~g}$ fresh mycelium per pot, nematodes (ca 5000 plantparasitic nematodes per pot) and a combination of fungus and nematodes. In total, $50 \mathrm{ml}$ of liquid solution was added to each pot divided into mycelium solution $(25 \mathrm{ml})$, nematodes $(25 \mathrm{ml})$ and tap water depending on the treatment.

The pots were placed in a randomized complete block design under artificial light (152 LUX in average) and moved once a week to provide a uniform exposure of light. The temperature in the growth chambers was set to $12{ }^{\circ} \mathrm{C}$. The pots were watered twice a week with tap water to ensure moist sand, and were fertilized at two occasions with a complete fertilizer (Blomstra N:P:K 100:18:86, Cederroth AB, Upplands Väsby, Sweden). In total, each plant received $177 \mathrm{mg} \mathrm{N}$.

\section{Harvest}

The pots were harvested block wise, starting 11 weeks after inoculation. The plant was taken out of the pot and the sand was removed. The plant was carefully washed and divided into stems, roots, stolons and tubers. The tubers were divided into small $(0.5-2 \mathrm{~cm}$ in diameter $)$ and large $(>2 \mathrm{~cm}$ in diameter) tubers. The plant parts were graded regarding nematode damage, stem canker, sclerotia and elephant hide (Supplemental Table 1). The submerged part of the main stem (from the seed tuber up to the surface level, 5-8 cm), the largest tuber and approximately ten roots were weighed separately and put in plastic bags for cold storage $\left(4{ }^{\circ} \mathrm{C}\right)$ for extraction of nematodes. The remaining plant parts were weighed and dried 
in $75{ }^{\circ} \mathrm{C}$ for $48 \mathrm{~h}$ for determination of dry weight. The seed tuber was also measured (length and diameter) and graded regarding nematode damage and sclerotia (black scurf). Twenty grams of the sand was placed in cold storage $\left(4{ }^{\circ} \mathrm{C}\right)$ for extraction of nematodes, while another $100 \mathrm{~g}$ of sand was dried in $105^{\circ} \mathrm{C}$ for $24 \mathrm{~h}$ for determination of water content.

\section{Nematode Extraction}

For nematode extraction, the plant material and sand were placed on vlieseline filters (Freudenberg Performance Materials, Weinheim, Germany) in mesh net sieves. The below ground part of the main stem and roots were cut into $1 \mathrm{~cm}$ pieces and the tubers were divided into four pieces and placed skin side down. The sieves were placed in Baermann funnels, and the nematodes were extracted for $24 \mathrm{~h}$, heat-killed and fixated in formalin (Viketoft et al. 2005). The number of nematodes was estimated in the suspensions from each extraction under low magnification (50×) and expressed as number of nematodes per gram dry weight of each plant part or per gram dry soil.

\section{Statistical Analyses}

Effects of additions of fungus and nematodes on dry weight of stems, tubers, roots and stolons were analyzed with randomized complete block design ANOVA using $\mathrm{R}$ version 3.1.1 ( $\mathrm{R}$ Core Team 2013). To account for heteroscedasticity, we used heteroscedastic consistent covariance estimation, packages multcomp (Hothorn et al. 2008) and sandwich (Zeileis 2004, 2006). If there was a significant interaction effect ( $p$-value $<0.05)$, the differences among treatments within potato cultivars were examined with the SLICE function in SAS version 9.3 (SAS Institute Inc., Cary, NC, USA). For stolons, it was not possible to use the SLICE function due to an interaction effect with block, so instead multiple comparisons were performed in R. Differences were considered significant if the $p$-value was $<0.01$ to account for multiple comparisons. The number of tubers and stems were analyzed with Poisson regression in $\mathrm{R}$, with the control treatment used as baseline.

To analyze the effect of fungal and nematode damage on stems and tubers we used a dichotomous variable - damage or no damage. The data was analyzed with binomial regression using $\mathrm{R}$. The number of nematodes in the different plant parts and in the potting medium was analyzed with randomized complete block design ANOVA in R with heteroscedastic consistent covariance estimation. Both the numbers of plantparasitic and fungal-feeding nematodes were analyzed, as they both can affect the performance of $R$. solani.

\section{Results}

The cultivars differed in emergence time, but there was no obvious difference among the treatments within cultivars. All plants treated with $R$. solani were infected by stem canker and black scurf. Plant-parasitic nematodes were present in all tested plant parts and in the potting medium from the pots where nematodes had been added. Plant-parasitic nematodes dominated the inoculated nematode community $(55 \%)$ and consisted of the taxa Pratylenchus (47\%), Tylenchorhynchus (7\%) and Trichodoridae $(0.2 \%)$. Bacterial-feeding nematodes were also common $(37 \%)$, while root-hair feeders $(4.8 \%)$, fungal feeders $(2.6 \%)$ and omnivores $(0.7 \%)$ were much less abundant. The fungal-feeding nematodes consisted of the genera Aphelenchus (0.2\%), Aphelenchoides $(2.0 \%)$ and Diphtherophora $(0.4 \%)$. Due to too few occurrences, it was not possible to statistically analyze the effect of treatment and cultivar on the number of fungal-feeding nematodes in the different plant parts and in the potting medium.

\section{Impact on Stems and Stolons}

The dry weight of stems were affected by cultivar $(\mathrm{df}=5$, $\mathrm{F}=30.89, p<0.001)$; cv. King Edward had the highest aboveground biomass and cv. Erika and cv. Fontane had the lowest (Fig. 1a). The dry weight of stems was not affected by treatment, and there were also no differences in the number of stems among treatments within the different cultivars (Table 2).

There were no differences in stem damage (nematodes, canker nor sclerotia) among the treatments and cultivars (Table 3). Sclerotia on stems are rarely found in field conditions, but were rather common in this experiment. Neither were there any significant effects of either cultivar or treatment on the number of plant-parasitic nematodes in the stems (Table 4). Fungal-feeding nematodes only occurred in a few stems of cv. Perlo, when fungus and nematodes were inoculated together (Table 4).

The stolons were often severely damaged by the fungus and were therefore few or very short, and in some cases even completely missing. Due to this fact, it was not possible to extract nematodes from them. But there was a significant interaction between treatment and cultivar for the dry weight of stolons ( $\mathrm{df}=15, \mathrm{~F}=1.95, p=0.03$ ). In cv. Kuras, there were more or longer stolons in the control treatment than in the nematode treatment and in the treatment with both fungus and nematodes (Table 2).

\section{Impact on Tubers}

The number of tubers differed among treatments in one of the cultivars (Table 2); cv. Erika had more tubers when both fungus and nematodes were added compared to the control $(p=0.04)$. As the dry weight of those tubers did not differ, 


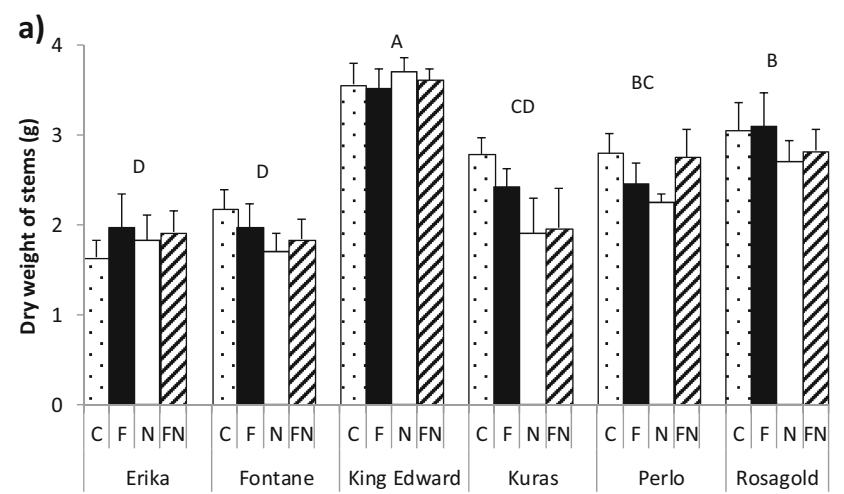

Table 2 Numbers and dry weights (mean (SE)) of different parts of potato plants subjected to different combinations of the plant pathogenic fungus Rhizoctonia solani and a full nematode community containing plant-parasitic nematodes

\begin{tabular}{|c|c|c|c|c|}
\hline Cultivar & Treatment & No. stems & No. tubers & $\begin{array}{l}\text { DW stolons } \\
(\mathrm{mg})\end{array}$ \\
\hline \multirow[t]{4}{*}{ Erika } & $\mathrm{C}$ & $2.5(0.2)$ & $4.2(0.6) \mathrm{b}$ & $40(8)$ \\
\hline & $\mathrm{F}$ & $3.5(0.2)$ & $5.2(1.2) \mathrm{ab}$ & $38(9)$ \\
\hline & $\mathrm{N}$ & $2.8(0.6)$ & $5.8(1.4) \mathrm{ab}$ & $57(11)$ \\
\hline & $\mathrm{F}+\mathrm{N}$ & $3.5(0.3)$ & $7.0(1.8) \mathrm{a}$ & $83(16)$ \\
\hline \multirow[t]{4}{*}{ Fontane } & $\mathrm{C}$ & $2.5(0.2)$ & $4.2(0.4)$ & $33(5)$ \\
\hline & $\mathrm{F}$ & $1.7(0.2)$ & $3.0(0.5)$ & $38(11)$ \\
\hline & $\mathrm{N}$ & $1.7(0.2)$ & $3.0(0.4)$ & $42(5)$ \\
\hline & $\mathrm{F}+\mathrm{N}$ & $2.3(0.2)$ & $3.3(0.4)$ & $33(10)$ \\
\hline \multirow[t]{4}{*}{ King Edward } & $\mathrm{C}$ & $1.0(0.0)$ & $5.8(1.2)$ & $220(35)$ \\
\hline & $\mathrm{F}$ & $1.3(0.2)$ & $4.2(1.0)$ & $232(30)$ \\
\hline & $\mathrm{N}$ & $1.2(0.2)$ & $7.0(1.3)$ & $265(45)$ \\
\hline & $\mathrm{F}+\mathrm{N}$ & $1.5(0.5)$ & $3.8(1.0)$ & $163(36)$ \\
\hline \multirow[t]{4}{*}{ Kuras } & $\mathrm{C}$ & $1.3(0.2)$ & $3.2(0.6)$ & $142(29) \mathrm{a}$ \\
\hline & $\mathrm{F}$ & $1.7(0.5)$ & $2.2(0.7)$ & 87 (11) ab \\
\hline & $\mathrm{N}$ & $1.7(0.2)$ & $3.3(0.6)$ & $60(14) \mathrm{b}$ \\
\hline & $\mathrm{F}+\mathrm{N}$ & $1.5(0.2)$ & $1.8(0.4)$ & $65(23) \mathrm{b}$ \\
\hline \multirow[t]{4}{*}{ Perlo } & $\mathrm{C}$ & $5.0(0.5)$ & $5.7(1.3)$ & 107 (16) \\
\hline & $\mathrm{F}$ & $5.2(0.7)$ & $4.7(0.4)$ & $68(15)$ \\
\hline & $\mathrm{N}$ & $4.8(1.0)$ & $3.8(0.4)$ & $57(3)$ \\
\hline & $\mathrm{F}+\mathrm{N}$ & $5.5(1.0)$ & $6.8(1.0)$ & $78(13)$ \\
\hline \multirow[t]{4}{*}{ Rosagold } & $\mathrm{C}$ & $2.0(0.4)$ & $3.7(0.9)$ & $107(32)$ \\
\hline & $\mathrm{F}$ & $1.7(0.3)$ & $2.5(0.9)$ & $92(27)$ \\
\hline & $\mathrm{N}$ & $1.5(0.3)$ & $2.5(0.6)$ & $85(15)$ \\
\hline & $\mathrm{F}+\mathrm{N}$ & $1.3(0.2)$ & $2.2(0.3)$ & $87(20)$ \\
\hline
\end{tabular}

Different letters indicate significant differences among treatments within cultivar $(p<0.05$ for tubers (Tukey-adjusted) and $p<0.01$ for stolons (non-adjusted))

Damage caused by nematodes were very rarely found on

Fig. 1 Dry weight (g; mean \pm SE) of (a) stems, (b) tubers and (c) roots of potato plants subjected to different combinations of the plant pathogenic fungus Rhizoctonia solani and a full nematode community containing plant-parasitic nematodes. Different letters indicate significant differences $(p<0.05)$; upper case letters indicate differences among cultivars and lower case letters differences among treatments within cultivars. $\mathrm{C}=$ control, $\mathrm{F}=$ fungus, $\mathrm{N}=$ nematodes, $\mathrm{FN}=$ combination of fungus and nematodes

cv. Erika produced more and smaller tubers in the combined treatment. Overall, the dry weight of tubers was affected both by treatment $(\mathrm{df}=3, \mathrm{~F}=4.73, p=0.004)$ and cultivar $(\mathrm{df}=5$, $\mathrm{F}=61.7, p<0.001)$ (Fig. 1b), but their interaction were insignificant. The dry weight of tubers were lower in the nematode treatment compared to the control $(p=0.005)$ and the treatment with only fungus $(p=0.005)$. This was especially evident in cv. Fontane, cv. Kuras and cv. Perlo. Among the cultivars, Fontane had the highest tuber yield and Kuras the lowest (Fig. 1b). the tubers (Table 3). There was no effect of neither treatment nor cultivar on occurrence of elephant hide, but incidence of black scurf was affected by cultivar $\left(\mathrm{df}=5, \chi^{2}=26.4\right.$, $p<0.001)$. Cultivar Perlo had higher likelihood of occurrence of black scurf compared to all other cultivars (Erika: $p<0.001$; Fontane: $p<0.001$; King Edward: $p<0.001$, Kuras: $p=0.03$, Rosagold: $p=0.002$ ), which is indicated as higher percentage of tubers with black scurf in cv. Perlo (Table 3). There was also higher likelihood of black scurf on cv. Kuras than on cv. King Edward ( $p=0.03$ ).

Although there was no visible nematode damage, except for two tubers of cv. Fontane and one tuber of cv. King Edward, the tubers did contain plant-parasitic nematodes and the abundance was higher when the nematodes occurred together with the fungus $(\mathrm{df}=1, \mathrm{~F}=5.43$, $p=0.02$ ) (Table 4). There were no fungal-feeding nematodes in the tubers (Table 4). 
Table 3 Percentage of stems and tubers with fungal and nematode damage. Nematode damage on stems were seen as brown stripes and on tubers as brown spots

\begin{tabular}{|c|c|c|c|c|c|c|c|}
\hline \multirow[t]{2}{*}{ Cultivar } & \multirow[t]{2}{*}{ Treatment } & \multicolumn{3}{|l|}{ Stems } & \multicolumn{3}{|l|}{ Tubers } \\
\hline & & Stem canker & Sclerotia & Nematode damage & Elephant hide & Black scurf & Nematode damage \\
\hline \multirow[t]{3}{*}{ Erika } & $\mathrm{F}$ & 62 & 10 & - & 29 & 13 & - \\
\hline & $\mathrm{N}$ & - & - & 76 & - & - & 0 \\
\hline & $\mathrm{F}+\mathrm{N}$ & 62 & 0 & 62 & 14 & 14 & 0 \\
\hline \multirow[t]{3}{*}{ Fontane } & $\mathrm{F}$ & 50 & 40 & - & 22 & 22 & - \\
\hline & $\mathrm{N}$ & - & - & 50 & - & - & 11 \\
\hline & $\mathrm{F}+\mathrm{N}$ & 50 & 7 & 57 & 30 & 15 & 0 \\
\hline \multirow[t]{3}{*}{ King Edward } & $\mathrm{F}$ & 50 & 13 & - & 28 & 4 & - \\
\hline & $\mathrm{N}$ & - & - & 43 & - & - & 3 \\
\hline & $\mathrm{F}+\mathrm{N}$ & 44 & 0 & 67 & 17 & 0 & 0 \\
\hline \multirow[t]{3}{*}{ Kuras } & $\mathrm{F}$ & 60 & 20 & - & 46 & 46 & - \\
\hline & $\mathrm{N}$ & - & - & 90 & - & - & 0 \\
\hline & $\mathrm{F}+\mathrm{N}$ & 56 & 11 & 78 & 27 & 18 & 0 \\
\hline \multirow[t]{3}{*}{ Perlo } & $\mathrm{F}$ & 81 & 0 & - & 14 & 68 & - \\
\hline & $\mathrm{N}$ & - & - & 69 & - & - & 0 \\
\hline & $\mathrm{F}+\mathrm{N}$ & 79 & 33 & 48 & 2 & 68 & 0 \\
\hline \multirow[t]{3}{*}{ Rosagold } & $\mathrm{F}$ & 50 & 40 & - & 20 & 27 & - \\
\hline & $\mathrm{N}$ & - & - & 44 & - & - & 0 \\
\hline & $\mathrm{F}+\mathrm{N}$ & 25 & 25 & 38 & 15 & 15 & 0 \\
\hline
\end{tabular}

\section{Nematodes in Roots and Potting Medium}

There was no difference among the treatments in the number of plant-parasitic nematodes in roots, but among the cultivars $(\mathrm{df}=5, \mathrm{~F}=4.75, p=0.001)$. Roots of $\mathrm{cv}$. Fontane contained more plant-parasitic nematodes than the roots of cv. King Edward ( $p=0.003)$, cv. Perlo $(p=0.002)$ and cv. Rosagold $(p<0.001)$ (Table 4). Fungal-feeding nematodes only occurred in the a few roots of cv. Perlo and cv. King Edward when fungus and nematodes were added together (Table 4).
There was a significant interaction between treatment and cultivar for the dry weight of roots ( $\mathrm{df}=15, \mathrm{~F}=1.87, p=0.03$ ) (Fig. 1c). In cv. Kuras, there were more roots in the control compared to the nematode treatment $(p=0.0073)$ and the treatment with both fungus and nematodes $(p=0.012)$. In cv. Perlo, there were also more roots in the control compared to the nematode treatment $(p=0.024)$, but also more roots in the treatment with both fungus and nematodes compared to the only nematode treatment $(p=0.0012)$.

There was also a significant effect of cultivar on the number of plant-parasitic nematodes occurring in the potting

Table 4 Numbers of plant-parasitic (PP) and fungal-feeding (FF) nematodes (per g dry weight, mean (SE)) in different plant parts of potato and in sand

\begin{tabular}{|c|c|c|c|c|c|c|c|c|c|}
\hline \multirow[t]{2}{*}{ Cultivar } & \multirow[t]{2}{*}{ Treatment } & \multicolumn{2}{|l|}{ Stems } & \multicolumn{2}{|l|}{ Tubers } & \multicolumn{2}{|l|}{ Roots } & \multicolumn{2}{|l|}{ Sand } \\
\hline & & PP & $\mathrm{FF}$ & PP & $\mathrm{FF}$ & PP & FF & PP & FF \\
\hline \multirow[t]{2}{*}{ Erika } & $\mathrm{N}$ & $40(17)$ & 0 & $0.05(0.05) \mathrm{b}$ & 0 & $283(81) a b$ & 0 & $0.06(0.03) a b$ & $0.01(0.01)$ \\
\hline & $\mathrm{F}+\mathrm{N}$ & $79(43)$ & 0 & $0 \mathrm{a}$ & 0 & $882(341) a b$ & 0 & $0.06(0.03) \mathrm{ab}$ & 0 \\
\hline \multirow[t]{2}{*}{ Fontane } & $\mathrm{N}$ & $36(22)$ & 0 & $0.11(0.08) b$ & 0 & $1322(427) \mathrm{a}$ & 0 & $0.14(0.05) \mathrm{a}$ & $0.03(0.03)$ \\
\hline & $\mathrm{F}+\mathrm{N}$ & $32(8)$ & 0 & $0.29(0.14) \mathrm{a}$ & 0 & 931 (214) a & 0 & $0.15(0.04) \mathrm{a}$ & $0.01(0.01)$ \\
\hline \multirow[t]{2}{*}{ King Edward } & $\mathrm{N}$ & $47(21)$ & 0 & $0.16(0.16) \mathrm{b}$ & 0 & 367 (159) b & 0 & $0.01(0.01) \mathrm{b}$ & 0 \\
\hline & $\mathrm{F}+\mathrm{N}$ & $16(8)$ & 0 & $0.83(0.76) \mathrm{a}$ & 0 & $393(134) \mathrm{b}$ & $6.9(5.1)$ & $0.03(0.02) b$ & 0 \\
\hline \multirow[t]{2}{*}{ Kuras } & $\mathrm{N}$ & $70(37)$ & 0 & $0.19(0.15) \mathrm{b}$ & 0 & $581(191) \mathrm{ab}$ & 0 & $0.07(0.05) \mathrm{ab}$ & 0 \\
\hline & $\mathrm{F}+\mathrm{N}$ & $18(10)$ & 0 & $1.06(0.50) \mathrm{a}$ & 0 & $580(203) \mathrm{ab}$ & 0 & $0.03(0.02) a b$ & 0 \\
\hline \multirow[t]{2}{*}{ Perlo } & $\mathrm{N}$ & $27(16)$ & 0 & $0.05(0.05) b$ & 0 & 418 (167) b & 0 & $0.08(0.03) \mathrm{ab}$ & $0.10(0.09)$ \\
\hline & $\mathrm{F}+\mathrm{N}$ & $11(4)$ & $6.7(5.4)$ & $0.87(0.74) \mathrm{a}$ & 0 & $179(56) \mathrm{b}$ & $10.9(5.6)$ & $0.04(0.02) \mathrm{ab}$ & 0 \\
\hline \multirow[t]{2}{*}{ Rosagold } & $\mathrm{N}$ & $53(19)$ & 0 & $0.09(0.09) \mathrm{b}$ & 0 & $341(101) b$ & 0 & $0.02(0.01) b$ & $0.04(0.03)$ \\
\hline & $\mathrm{F}+\mathrm{N}$ & 44 (17) & 0 & $0.67(0.58) \mathrm{a}$ & 0 & $243(74) b$ & 0 & $0.02(0.01) b$ & $0.03(0.01)$ \\
\hline
\end{tabular}

Different letters indicate significant differences $(p<0.05)$ among treatments (tubers) or among cultivars (roots and sand) 
medium ( $\mathrm{df}=5, \mathrm{~F}=5.09, p<0.001)$, with more plantparasitic nematodes in the sand in pots with cv. Fontane compared to cv. King Edward $(p<0.001)$ and cv. Rosagold $(p<0.001)$ (Table 4). Fungal-feeding nematodes occurred in the sand of four of the cultivars (Erika, Fontane, Perlo, Rosagold), in both the only nematode treatment and in the combination treatment (Table 4).

\section{Discussion}

In contradiction to the hypothesis, no synergistic interaction between $R$. solani and free-living plant-parasitic nematodes on tuber yield was found, although there was an effect of treatment with lower tuber yield in the nematode treatment. The cultivars differed in several aspects, for example incidence of black scurf, dry weight of stems and tubers, and as hypothesized they also responded quite differently to the treatments. Especially the effect of the treatments on the dry weight of stolons and roots varied among the cultivars. We are aware of that our results are based on a single experiment but for each experiment there is a trade-off between repeating in time and precision, and in this case each treatment is repeated six times giving a good precision in the estimated treatment effects. In addition, other comparable experiments with one of the cultivars (King Edward) have produced similar results and those data will be included in a future manuscript (Edin et al., unpublished data).

One reason for the lack of synergistic interaction could be that we used a full nematode community, instead of adding the root-lesion nematode $P$. penetrans as in our previous experiment (Viketoft et al., unpublished data). The plant-parasitic nematodes in the full nematode community were mostly P. crenatus but also P. neglectus occurred. Pratylenchus penetrans is a more aggressive root-lesion nematode (Castillo and Vovlas 2007) and it is in experiments with that particular species a synergistic interaction with $R$. solani previously has been found (Kotcon et al. 1985; Viketoft et al., unpublished data). But as P. penetrans usually are more harmful, it is contradictory that there is a stronger effect of nematodes on tuber yields in the present study. Both P. neglectus and P. crenatus are found in potato fields (Florini et al. 1987; Mahran et al. 2010; Esteves et al. 2015; Forge et al. 2015), and at least $P$. neglectus has previously been shown to result in potato yield losses (Florini et al. 1987; Olthof 1990; Forge et al. 2015). For root-lesion nematodes, yields can be related to the tolerance of the potato cultivars to nematode colonization (Bernard and Laughlin 1976). In the present study, the cultivars supported nematode populations of different sizes in their roots but it is difficult to distinguish differences in tolerance among the cultivars as there was a general decrease in tuber yield due to the nematodes.
On the other hand, the effect of $R$. solani on tuber yields was weaker than in our previous study, as for cv. King Edward the potato plants subjected to only fungus performed substantially better in the present study. However, the overall yields, both above and belowground, in the present study are substantially lower than in the previous study (Viketoft et al., unpublished data), possibly dependent on the fact that these plants received less nutrients, although they did not show any signs of nutrient deficiency.

Although there was no interaction effect on tuber yield, the tubers contained more plant-parasitic nematodes when the nematodes were inoculated together with the fungus. This suggests that the nematodes are affected by the fungus and not the other way around. As $R$. solani only are present at the surface of the potato peel, there is the possibility that the fungus weakens the peel allowing easier penetration by the nematodes.

It was not surprising that we found differences in tuber yield among the cultivars. The cultivars were chosen to include both early and late maturing varieties. The cultivars that mature later develop more slowly and therefore can be expected to have lower tuber yield when harvested at the same time as early maturing cultivars. In addition, the cultivar with the lowest tuber yield in our experiment, cv. Kuras, is a starch potato with low number of tubers per plant. The two cultivars with highest yield in our experiment, cv. Fontane and cv. Perlo, were also the ones with very high average yield according to the producer (Table 1).

As a result of infection by $R$. solani, the stolons are usually very short or even missing (Banville 1989) and that was also the case in the present study. However, here the amount of stolons also depended on the cultivar. King Edward was the cultivar that had more or longer stolons than the other cultivars. In one of the cultivars, cv. Kuras, there was a negative effect of nematodes on the weight of stolons, which could be one contributing factor to the lower tuber yield in the nematode treatment in this cultivar. The effect of nematodes on the incidence and damage severity of canker on stolons has been shown in the majority of studies concerning potato cyst nematodes and R. solani (Back et al. 2006; Bhattarai et al. 2009). In the present study, we could not see an effect of nematodes on the incidence of stolon canker as they all were heavily damaged by the fungus and there were mostly too few stolons for extraction of nematodes.

Usually, the performance of roots is not estimated when the interaction effect of fungal pathogens and plant-parasitic nematodes are investigated on potato (Back et al. 2006, 2010; Bhattarai et al. 2009; Bhattarai et al. 2010; Kotcon et al. 1985). In the present study, the dry weights of roots were negatively affected by the presence of nematodes in cv. Perlo and cv. Kuras. This was not dependent on the number of plant-parasitic nematodes in the roots of these cultivars, as these were not more abundant than in the other cultivars. Instead, cv. Fontane clearly supports the largest quantity of 
plant-parasitic nematodes, whereas the dry weight of the roots was similar to the other cultivars. One possibility is that $\mathrm{cv}$. Perlo and cv. Kuras differ in the anatomy of their roots (Storey and Evans 1987), making them more vulnerable to nematode damage and leading to less root growth.

Since we used a full nematode community as inoculum there were also fungal-feeding nematodes present in the pots, and potentially these nematodes may affect $R$. solani. Previous studies have shown the ability of fungal-feeding nematodes to suppress plant diseases (Friberg et al. 2005; Lagerlöf et al. 2011). In the present study, the number of fungal-feeding nematodes was probably too low to have an effect on the performance of $R$. solani. However, there was a tendency for higher abundance of these nematodes in the treatment where both nematodes and fungus were inoculated, suggesting that they at least were stimulated by the presence of the fungus. Fungal-feeding nematodes are not known to inhabit plant tissue but they may have entered the stems in the cankers made by the fungus since they were found in some stems.

In conclusion, no synergistic effect was found between free-living plant-parasitic nematodes and $R$. solani in the present study. However, interestingly the dry weight of tubers was lower in the nematode treatment compared to the control and the fungus treatment. The cultivars differed in incidence of black scurf and in dry weight of stems and tubers. In addition, the effect of treatments on the dry weight of stolons and roots also varied among the cultivars. Therefore, results concerning incidence of $R$. solani and/or plant-parasitic nematodes found for one cultivar may not be applicable to other cultivars.

Acknowledgements We thank Jonas Kardell for help with the statistical analyzes, and Johanna Jernberg for help during the harvest of the experiment. This study was founded by The Swedish Farmers' Foundation for Agricultural Research.

Open Access This article is distributed under the terms of the Creative Commons Attribution 4.0 International License (http:// creativecommons.org/licenses/by/4.0/), which permits unrestricted use, distribution, and reproduction in any medium, provided you give appropriate credit to the original author(s) and the source, provide a link to the Creative Commons license, and indicate if changes were made.

\section{References}

Back, M.A., P.P.J. Haydock, and P. Jenkinson. 2002. Disease complexes involving plant parasitic nematodes and soilborne pathogens. Plant Pathology 51: 683-697.

Back, M., P. Haydock, and P. Jenkinson. 2006. Interactions between the potato cyst nematode Globodera rostochiensis and diseases caused by Rhizoctonia solani AG3 in potatoes under field conditions. European Journal of Plant Pathology 114: 215-223.

Back, M., P. Jenkinson, T. Deliopoulos, and P. Haydock. 2010. Modifications in the potato rhizosphere during infestations of Globodera rostochiensis and subsequent effects on the growth of Rhizoctonia solani. European Journal of Plant Pathology 128: 459-471.
Banville, G.J. 1989. Yield losses and damage to potato plants caused by Rhizoctonia solani Kühn. American Potato Journal 66: 821-834.

Bernard, E.C., and C.W. Laughlin. 1976. Relative susceptibility of selected cultivars of potato to Pratylenchus penetrans. Journal of Nematology 8: 239-242.

Bhattarai, S., P.P.J. Haydock, M.A. Back, M.C. Hare, and W.T. Lankford. 2009. Interactions between the potato cyst nematodes, Globodera pallida, G. rostochiensis, and soil-borne fungus, Rhizoctonia solani (AG3), diseases of potatoes in the glasshouse and the field. Nematology 11: 631-640.

Bhattarai, S., P.P.J. Haydock, M.A. Back, M.C. Hare, and W.T. Lankford. 2010. Interactions between field populations of the potato cyst nematode Globodera pallida and Rhizoctonia solani diseases of potatoes under controlled environment and glasshouse conditions. Nematology 12: 783-790.

Bowers, J. 1996. Infection and colonization of potato roots by Verticillium dahliae as affected by Pratylenchus penetrans and P. crenatus. Phytopathology 86: 614-621.

Carling, D.E., R.H. Leiner, and P.C. Westphale. 1989. Symptoms, signs and yield reduction associated with rhizoctonia disease of potato induced by tuber-borne inoculum of Rhizoctonia solani AG-3. American Potato Journal 66: 693-701.

Castillo, P., and N. Vovlas. 2007. Pratylenchus (Nematoda: Pratylenchidae): diagnosis, biology, pathogenicity and management. Leiden: Brill.

Djébali, N., and T. Belhassen. 2010. Field study of the relative susceptibility of eleven potato (Solanum tuberosum L.) varieties and the efficacy of two fungicides against Rhizoctonia solani attack. Crop Protection 29: 998-1002.

El Aziz, A.R.M.A., M.R. Mahmoud, M.A. Al-Othman, E.M. El-Sherif Abdel-Sattar, and H. El-Marzouky. 2013. Differential interaction between isolates of Rhizoctonia solani AG-3 and potato cultivars. African Journal of Microbiological Research 7: 1045-1054.

Esteves, I., C. Maleita, and I. Abrantes. 2015. Root-lesion and root-knot nematodes parasitizing potato. European Journal of Plant Pathology 141: 397-406.

Evans, K. 1987. The interactions of potato cyst nematodes and Verticillium dahliae on early and maincrop potato cultivars. Annals of Applied Biology 110: 329-339.

Florini, D.A., R. Loria, and J.B. Kotcon. 1987. Influence of edaphic factors and previous crop on Pratylenchus spp. population densities in potato. Journal of Nematology 19: 85-92.

Forge, T.A., F.J. Larney, L.M. Kawchuk, D.C. Pearson, C. Koch, and R.E. Blackshaw. 2015. Crop rotation effects on Pratylenchus neglectus populations in the root zone of irrigated potatoes in southern Alberta. Canadian Journal of Plant Pathology 37: 363-368.

Friberg, H., J. Lagerlöf, and B. Rämert. 2005. Influence of soil fauna and fungal plant pathogens in agricultural and horticultural systems. Biocontrol Science and Technology 15: 641-658.

Hothorn, T., F. Bretz, and P. Westfall. 2008. Simultaneous inference in general parametric models. Biometric Journal 50: 346-363.

Kandouh, B., and B. Sipes. 2014. Differences among red-skinned potato cultivars and their response to Meloidogyne species. Nematropica 44: 47-50.

Kotcon, J.B., D.I. Rouse, and J.E. Mitchell. 1985. Interactions of Verticillium dahliae, Colletotrichum coccodes, Rhizoctonia solani, and Pratylenchus penetrans in the early dying syndrome of Russet Burbank potatoes. Phytopathology 75: 68-74.

Lagerlöf, J., V. Insunza, B. Lundegårdh, and B. Rämert. 2011. Interaction between a fungal plant disease, fungivorous nematodes and compost suppressiveness. Acta Agriculturae Scandinavica Section B - Soil and Plant Science 61: 372-377.

Lax, P., M.D. Tordable, J. Macagno, P. Bima, and M.E. Doucet. 2013. Response of different potato cultivars to the presence of Nacobbus aberrans. Nematropica 43: 83-90. 
Mahran, A., M. Tenuta, T. Shinners-Carenelly, M. Mundo-Ocampo, and F. Daayf. 2010. Prevalence and species identification of Pratylenchus spp. in Manitoba potato fields and host suitability of 'Russet Burbank'. Canadian Journal of Plant Pathology 32: 272282.

Muzhinji, N., J.W. Woodhall, M. Truter, and J.E. van der Waals. 2014. Elephant hide and growth cracking on potato tubers caused by Rhizoctonia solani AG3-PT in South Africa. Plant Disease 98: 570.

Mwaura, P., B. Niere, and S. Vidal. 2015. Resistance and tolerance of potato varieties to potato rot nematode (Ditylenchus destructor) and stem nematode (Ditylenchus dipsaci). Annals of Applied Biology 166: $257-270$.

Olthof, T.H.A. 1983. Reaction of six potato cultivars to Pratylenchus penetrans. Canadian Journal of Plant Pathology 5: 285-288.

Olthof, T.H.A. 1990. Reproduction and parasitism of Pratylenchus neglectus on potato. Journal of Nematology 22: 303-308.

R Core Team. 2013. R: A language and environment for statistical computing. R Foundation for Statistical Computing, Vienna. URL http://www.R-project.org/

Sedláková, V., J. Dejmalová, P. Doležal, E. Hausvater, P. Sedlák, and P. Baštová. 2013. Characterization of forty-four potato varieties for resistance to common scab, black scurf and silver scurf. Crop Protection 48: 82-87.

Storey, G.W., and K. Evans. 1987. Interactions between Globodera pallida juveniles, Verticillium dahliae and three potato cultivars, with descriptions of associated histopathologies. Plant Pathology 36: 192-200.

Viketoft, M., C. Palmborg, B. Sohlenius, K. Huss-Danell, and J. Bengtsson. 2005. Plant species effects on soil nematode communities in experimental grasslands. Applied Soil Ecology 30: 90-103.

Wallace, H.R. 1978. The diagnosis of plant diseases of complex etiology. Annual Review of Phytopathology 16: 379-402.

Whitehead, A.G., and J.R. Hemming. 1965. A comparison of some quantitative methods of extracting small vermiform nematodes from soil. Annals of Applied Biology 55: 25-38.

Zeileis, A. 2004. Econometric computing with HC and HAC covariance matrix estimators. Journal of Statistical Software 11: 1-17.

Zeileis, A. 2006. Object-oriented computation of sandwich estimators. Journal of Statistical Software 16: 1-16.

Zhang, X., Z. Yu, and J. Hao. 2014. Laboratory and field evaluations of potato cultivars for resistance to potato stem canker caused by Rhizoctonia solani AG2-1. Phytopathology 104: S3.316. 